\title{
Effective Processing of the Iron Ores
}

\author{
Vadim Kuskov ${ }^{1, *}$, Yana Kuskova ${ }^{1}$, Vladimir Udovitsky ${ }^{2}$ \\ ${ }^{1}$ Saint-Petersburg Mining University, 21 Line, 2, St. Petersburg, 199106, Russian Federation \\ ${ }^{2}$ T.F. Gorbachev Kuzbass State Technical University, 650000, 28 Vesennyaya St., Kemerovo, Russia
}

\begin{abstract}
Effective technology for a complex wasteless processing of the iron ores has been designed and includes three main components (plats): comminution plant, briquette plant, pigment plant. The comminution is done per energy effective technology. Using of briquetting for ores clotting enables the costs cut and brings to a higher level of environmental safety of the process. Briquette formation can be done as a regular pressing, as an extrusion. Developed technology allows to produce high quality competitively products for metallurgy industry and red iron oxide pigments. The whole production line impacts the environment in a minimal manner.
\end{abstract}

\section{Introduction}

Iron is the most widely adopted metal in industry today. Iron ores are the primary source for iron melting. Almost all of the iron ores are transformed into steel, cast iron and iron based alloys. Cast iron and steel are the fundaments of modern industries. The processing of iron products goes in a few stages. Usually it is mining, mineral processing, agglomeration, casting, depuration. Each step essentially increases the cost of production.

Competitiveness of national iron ore producers can be achieved on the world and domestic market with increase of products quality, decrease of costs, producing with high added value and complex usage of mineral raw materials.

The iron ores are falling into the following classes - high grade ore, ordinary grade ore, and low grade ore. Most of the iron ore deposits in Russian Federation are known for showing comparatively low grade ores and are consequently subjects for a necessity of ore dressing that requires obligatory intense grinding. The result is that such concentrates are not adopted for direct utilization in metallurgic separation and require clotting. Currently two methods of the iron ore clotting are found industrially efficient: agglomeration and pelletizing. Agglomeration is a process of sintering powder products with high temperature of burning fuel. Pelletizing is a process of producing pellets, based on the property of humid fine particles to roll into a spherical grain (pellet). Besides being wide spread these processes have both a sort of disadvantage. Sinter cannot be transported on a long distance and stored for a long period. Pellets can be used only for fine products. For instance, pelletizing and agglomeration need heating of the product to high temperature parameters, then the finished product cooled down and heated again in blast furnace thus leading to inefficient energy allocation. Within these

\footnotetext{
*Corresponding author: opikvb@mail.ru
} 
processes a lot of fine particles form that have negative side for blast furnace effectiveness. That is why these particles are sieved for the later removal and thus an abundance of by product arises. An alternative to agglomeration and pelletizing is the briquetting process. Briquetting is a process of mechanical and thermo mechanical briquette making that can be used for various raw materials, e.g. pieces with regular shape and size.

Besides producing various ferrous alloys, iron ore can be used for other industries, for example, pigments production. Pigments is a fine compounds, insoluble in water, organic solvents, firm forming agents and etc, with special optical, mechanical and sorbing properties. Pigments can be organic and non-organic. It can be natural and synthetic. Non-organic pigments includes iron oxide pigments, which also can be natural and synthetic. Iron oxide pigments are the most frequently used among colour pigments. The colour of pigments is determined by iron oxides: $\mathrm{FeO}, \mathrm{Fe}_{2} \mathrm{O}_{3}, \mathrm{Fe}_{3} \mathrm{O}_{4}$. Iron oxide pigments have wide colour palette due to chemical compounds diversity.

\section{Subject of investigation}

Besides relatively low grade iron ores Russian Federation has deposits of what is mostly known as high grade ores. These are usually result products of natural quartz iron rock dressings formed within long period under weathering or metamorphosis impacts. An example of such ore are ones found in Yakovlev deposits. The deposit is unique, it is mined by Yakovlev underground mine. The ores of the deposit have miscellaneous mineral composition. Follow general mineralogical types of ores were determined: micaceous iron oxide and martite; martite-hydrohematite; hydrohematite-hydrogothite, etc. As a mean content of $60.5 \%$ iron along deposit. Harmful contaminants content (S, P, etc.) is minimal. The most common ores in the deposit are micaceous iron oxide and martite ores with the highest iron content [1, 2].

As the investigations showed special sort of martite-hydrohematite ores is an excellent base for manufacture of red iron oxide pigments.

\section{Substantiation and developing of complex iron ore processing}

The investigations showed the ore can be an excellent primary product for metallurgical industry due to low harmful contaminants (production of high quality cast, steel, ferrous alloys). One of its types (pigment type) is excellent base for manufacture of red iron oxide pigments.

But these are mouldy on the contrary and are requiring agglomeration. In present the ore is sintered. An alternative to agglomeration may be presented by briquetting especially by the so called cold briquetting when the final pellets are not heated to a high $\mathrm{C}^{\circ}$. From the point of technology and economy cold briquetting has a range of advantages to compare with other methods of agglomeration. First, this process is cheaper than common agglomeration and it has much better environmental characteristic as compared to the traditional ones. Second, rather simple technological process and possibility to use flux with wide PSD (from 0 to $10 \mathrm{~mm}$ and more). Third, the addictives can be easily put in the flux. Fourth, briquettes have higher density, strength and transportability to compare with sinter. Fifth, ore contains the minimum of harmful contaminants; it can be agglomerated with unroasted method, in briquettes the composition and properties will remain. Sixth, briquetting is more environmental friendly than sintering and pelletizing [3-5]. Red iron oxide pigments price is much higher than price of iron ore concentrate. The share of Russian Federation in a global iron oxide pigment manufacture is below $1 \%$. Meaning that the country imports almost all of its consumed pigment. Currently 
the main product to produce in Russian Federation is synthetic red iron oxide pigment. There is no industrially developed production of natural iron oxide pigment in Russia nowadays. Cost of natural iron oxide pigment is two times less to compare with synthetic pigments. Taking into consideration the characteristic the natural iron oxide pigment has no analogues as being cheap in comparison to the others and as per crucial quality standard matches the best counterparts of synthetic iron oxide pigment. As per some characteristic the pigment even surpasses its synthetically revised counterparts. It almost doesn't contain sulfur and chlorine ions, has optimal particle size distribution. Pigment may be applied for paint and coating industries, anti corrosion primers, liners, dry compounds, wall plasters on cement, colour source for the concrete items (roof tiles, colorful floor tiles, pavement tiles), for dying caoutchouc compound, rubbers, leathers, paint manufactures adopted in marine industry, glass, glass wares, ceramics, polishing liquid, food industry.

The research of briquettes production has been established for briquettes for metallurgical industry and pigments for paint production. Within the research carried the technology of complex wasteless processing of high grade iron ores was evaluated. The general physical and metallurgical properties of briquettes are known: fineness, coverage rate, oil adsorption, etc.

It should be mentioned that during the researches the prospect of processing iron ore with iron content $69 \%$ and more ("superconcentrate") has been evaluated. It can be a raw material for direct reduced iron. The concentrates can be produced with environment friendly (without flotation) methods, for example, sensor-based sorting, fine and ultrafine classification, special methods of magnetic separation and flocculation, etc. Also the opportunity to create ultrafine paint raw material has been shown for special purpose pigments. Other type of ores can be used as sorbents. The data is not included in the paper. The technology of complex processing high grade iron ores unites three main components (plants) - comminution plant, briquette plant, pigment plant. Selective ore mining enable separate feed of metallurgy class and pigment class for re-fabrication.

In comminution plant the feed material is crushed and screened. Within the stages of crushing and screening of metallurgy class we do receive large particles that is further lead to metallurgy treatment thus enabling for the energy efficiency as per the principle "should not we crush what we should not crush". (The size of particles crushing and screening can change in collision with the granulometry content of the initial compound). The products of small mesh size later transported to the briquette plant into the preservation bunkers.

Metallurgic class of the ore is subject to briquetting as well as sands of initial classifications and magnet fractions from the pigment plant that are the byproduct of pigment. This enables efficient raw compound utilization. These product is mixed with a binder agent and the bonded material formed in briquettes. Further the briquettes meets screening to throw non conditional in terms of size briquettes that are returned into mixing stage. Briquettes that meet requirements of size pass to dryer zone. The dryer temperature depends on the binder type. For some types the drying process with an additional temperature is quite not needed. Several types of agents are applied for briquettes production during evaluation procedure$\mathrm{CMC}$, molasses, modified vinyl acetates, concrete, bentonite, liguid glass and other ones. Dry briquettes are screened and after we have: non-conditional briquettes are returned to the process and final product is stored and transported.

As it is known, the roll presses are frequently used for briquettes producing with binder compounds. The general advantages are versatility, rather simple construction, high capacity, absence of dynamic loads, small dimensions, reliability in intense mechanical and thermal loads. But a few disadvantages should be mentioned. For example, the asymmetric briquettes are formed due to a slight cell displacement. The strength of the briquettes is low, sometimes the briquettes are torn apart. The surface of cells should be ideal smooth, without any roughness. The bond material should have less adhesion properties to compare with the slurry. 
Otherwise the roughness brings to higher adhesion and sticking during the exploitation and as a result - destruction of the wet briquettes. Either the irregularity of roll bondage wearing (the central part wears faster than the sides) and inconstant pressure due to the irregular fill of cells.

That is why the screw press (extruder) was tested with binders. The idea of the method is to form the material of different length with pressure in die with a special profile. The main advantages of extrusion formation are: high strength of the briquettes right after the die, low capital costs and exploitation, rather low energy consumption for forming, slightly lower binder agent loss, chance to have the finished product of various sizes and cross section types on the same machines as well as option to process highly sticky (up to 20\%) product effectively. Extrusion technology is quite similar to press one. The extruder for formation is used instead of roll press.

The developed briquetting technology is quite flexible and setup due to customer requirements. E.g. the shape and size of briquettes and extrudats can be easily modified with forming zones of the machine. The strength, waterproof and other properties can be changed with pressure, drying settings, adding other type of binder. The technology is energy efficient.

As the investigation unveiled, the briquettes and extrudats are adaptable for metallurgy industry utilization. «Pigment» ore type is located in different fields of the deposit. To let plant work without any technologic interruptions is thanks to warehouse close to the pigment plant. Selective «pigment» ores type after crushing is accumulated in the consolidation warehouse.

To the pigment finalization the crushed paint grade of row material (pigment type) fed onto the mill from warehouse, mill fills the magnetic separator with low magnetic field. Magnetic fraction clarified on the separator is composed of mainly magnetite relict that are harmful agent for pigments. This fraction goes to briquette plant. Non magnetic fraction falls into final classification steps (in spiral classifier area). Sands after the classifier also passed to briquette plant. Classifier passes to cleaning and control classification stages in the hydrocyclone of different diameters. The classifier overflow to the cleaning hydro-cycloning first and after to the ultrasound clarification. Underflow of cleaning operations pass to I control hydro-cycloning leading also to the ultrasound clarification via the output frames and the sands itself to II control hydro-cycloning. An underflow of II control hydro-cycloning back onto cleaning step and underflow to control classification. Ultrasound clarification is applied if increased raw material sulfide contents. After the ultrasound clarification the material thickens and dries. The dried pigment transported for packing and delivery to client or to the finished product storage. Produced pigment is suitable for paint and coating industries and others. The technique of concentration raw ore on shaking tables as alternative to the magnet separations has also been adopted. The utilization of tables enabled complete exclusions of the ultrasound clarification of products as sulfide containing mineral can almost completely be evolved to the corresponding product. The scheme of pigment processing is technologically flexible, i.e. it is easy to modify and automate. It is coming from that classifiers (hydrocyclones) are simply adapted. The fineness of the pigment can be easily changed. The amount of hydrocyclones, assemble place, type of hydrocyclones is also modifying because it is moveable and rather cheap equipment. The processing is environmental friendly with no chemical and flotation processes involved.

\section{Future prospects}

Positive aspects for developing the metallurgical briquettes production are: almost unlimited mineral raw resources; rather low capital costs (lower than sinter and pelletizing processes); lower costs of production to compare with sinter and pelletizing; high ecological clearness of the process to compare with sinter and pelletizing, the process can be established close to the 
mine; good transportability of the product; convenient location that minimizes transport costs [6-10]. Positive aspects for developing the red iron oxide pigments production from enriched iron ores are: low capital costs and low producing costs with the resulted high quality product, it is connected with simple and flexible technology and unlimited access to raw materials; import replacement claim and lack of national products in international sanctions situation; lack of competitors on domestic and global market; possibility for expansion of market place due to stable demand; absence of high quality product on the national market with moderate price; environmental friendliness of the processing and the product; end of the economical crisis and market growth.

Follow prospects are: the increase of the capacity; production of briquettes for direct reduced iron. Addiction to the pigments market, replacement in a prospect of a certain synthetic red iron oxide pigment brands due to high quality and low costs of the production. Production of ultrafine pigments for special cases.

\section{Conclusion}

Thus, a technology of rational wasteless processing of the high grade iron ore has been promoted granting release of a high quality products for metallurgy industries equaling the existing industrial analogues and red iron oxide pigment quite demanded as well applied in paint and coating industries and in many other. The technology examined here has minimal effect on ecological issues.

\section{References}

1. V.P. Orlov et al., Iron ores KMA (Moscow, Publisher Geoinformark, 2001)

2. I. Túnyi, D. Vass, S. Karoli, J. Janocko, E. Halásová, A. Zlínská, B. Beláček, Geol. Carp., 56:3, 273-384 (2005)

3. V.B. Kuskov, J.V. Kuskova, A.V. Kornev, V.L. Trushko. Preparation of iron ore for metallurgical processing. CIS Iron and Steel Review, 2011, p. $4-5$.

4. V.B. Kuskov, A.V. Kornev. Briquettes for metallurgical industry. CIS Iron and Steel Review, 2011, p. $6-7$.

5. V.L. Trushko, R.E Dashko, V.B. Kuskov, A.V. Kornev, Mining university notes, 194, 120 (2011)

6. V.B. Kuskov, Y.V. Kuskova, A.I. Mikheyev, I.S. Rogova, CIS Iron and Steel Review 7 (2009)

7. V.B. Kuskov, Y.V. Kuskova, Metallugist, 3, 70 (2010)

8. V.B. Kuskov, Y.V. Kuskova, Metallurgist, 54, 192 (2010)

9. A.S. Klyamko, V.L. Trushko, V.B. Kuskov, Mining university notes, 197, 245 (2012)

10. V.B. Kuskov, Y.V. Kuskova. V.L. Trushko, Processing of ores 1, 39 (2014) 
